\title{
Exploring Research Trends and Building a Multidisciplinary Framework Related to Brownfield: A Visual Analysis Using CiteSpace
}

\author{
Xinjia Zhang $\mathbb{D}^{1},{ }^{1}$ Yang Song $\mathbb{D},{ }^{1,2}$ Shijun Wang $\mathbb{D},{ }^{1,2}$ and Sitong Qian ${ }^{1}$ \\ ${ }^{1}$ School of Geographical Sciences, Northeast Normal University, Changchun 130024, China \\ ${ }^{2}$ Key Laboratory of Geographical Processes and Ecological Security in Changbai Mountains, Ministry of Education, \\ Changchun 130024, China
}

Correspondence should be addressed to Yang Song; song0317@nenu.edu.cn and Shijun Wang; wangsj@nenu.edu.cn

Received 13 August 2020; Revised 16 September 2020; Accepted 15 December 2020; Published 22 January 2021

Academic Editor: Jun Yang

Copyright (C) 2021 Xinjia Zhang et al. This is an open access article distributed under the Creative Commons Attribution License, which permits unrestricted use, distribution, and reproduction in any medium, provided the original work is properly cited.

\begin{abstract}
Brownfield has become one of the critical issues in modern cities. Over the past few decades, a considerable number of papers on brownfield research have been published. This study reviewed 773 documents themed with "brownfield" in the Web of Science core database between 1980 and 2020 and used the CiteSpace software to sort out the spatial and temporal distribution, knowledge groups, subject structures and hotspot fields, and evolutionary trends of global brownfield research. The analysis focuses on distribution of lead authors and their institutions, high-frequency categories and keywords, high influential journals, author contribution, and evolutionary trends based on coword analysis, coauthor analysis, cocitation analysis, and cluster analysis of documents. On the basis of the aforementioned keywords, clusters, and citation bursts analysis, this paper establishes a multidisciplinary framework for brownfield research, suggesting the main research directions for the future development, which provides theoretical support and practical guidance for the research direction of future brownfield research.
\end{abstract}

\section{Introduction}

The whole process of urban development is accompanied by urban renewal. With the adjustment of the industrial structure and the decline of industrial zones, a large amount of brownfield has been produced inside cities, exerting an extremely adverse impact on their economy, society, and environment. The term brownfield first appeared in the Comprehensive Environmental Response Compensation and Liability Act (CERCLA, also known as the "Superfund"), passed by the United States Congress in 1980. In this law, brownfield was defined as "abandoned, idled, or underused industrial and commercial facilities where expansion or redevelopment is complicated by real or perceived environmental contamination" [1]. At present, a number of different definitions of brownfield can be found in federal, state, and local laws and programs. All these definitions share the following characteristics attributed to brownfields: (i) they have been affected by former uses of siting or surrounding land; (ii) they are derelict or underused; (iii) they are mainly located in fully or partly developed urban areas; (iv) they require intervention to restore them to a beneficial use; and (v) they may have real or perceived contamination problems [2].

Brownfield issues have attracted the attention of academics and practitioners. Worldwide cities are facing the problems of severe soil pollution and waste of land resources; the reasonable redevelopment of brownfield will be beneficial for alleviating environmental pressure, relieving the shortage of urban land, controlling urban sprawl, and stimulating economic growth. The basic research on brownfield in Europe and North America is earlier and more solid. Existing research focuses on on-site remediation [3], policy, market [4,5], economic measures, liability for compensation [6,7], risk assessment [8], and brownfield redevelopment $[9,10]$. Adams et al. [11] compared 
brownfield development policies in North America and Britain and sought to assess whether the main differences in understanding and tackling brownfield can be attributed primarily to physical, cultural, or institutional factors. Kovacs and Szemmelveisz [12] reviewed the treatment of heavy metal soil contaminants. Keely et al. [13] provided an interdisciplinary literature review of the social science of environmental cleanup. The reviewed article by Song et al. [14] summarizes the main features of the National Bureau of Statistics, as well as key technology choices, case studies, limitations, and future trends for urban contaminated land remediation and brownfield redevelopment. Oudes and Stremke [15] analyzed 61 papers on landscape quality and the role of design, governments, and participation, illustrating how executed projects influence the discourse on landscape transformation and providing valuable insights for the design of renewable energy landscapes. Ameller et al. [16] analyzed how economists have contributed to removing some of the barriers that prevent or restrict brownfield redevelopment, providing pathways for future research. Lin et al. [17] used the CiteSpace software to scientifically analyze the knowledge structure, hotspots, research trends, and other aspects of the brownfield at a global level. There is no lack of research on the hot topics on brownfield research; however, the majority of these studies started from the single viewpoint of brownfield development policy and remediation methods, in which the development trend and the research context of brownfield were not systematically organized and summarized.

On the basis of existing literature, we collected and read the scientific literature on brownfield included in the Web of Science core database in the period 1980-2020, with the aim to (i) explore the current research status in the field of brownfield through knowledge mapping, (ii) identify the key countries and institutions, (iii) identify the key authors and subject categories, (iv) identify the cocitation clusters, and also (v) propose the main further development of brownfield research. In this way, it is possible to enrich and deepen the research on brownfield and provide scientific guidance for the redevelopment of brownfield and for sustainable economic and social development.

\section{Methodology}

2.1. CiteSpace Knowledge Mapping Analysis. Knowledge domain maps are a series of different graphs showing the relationship between the knowledge development process and the structure. They use visual technology to describe knowledge resources and their carriers and mine, analyze, construct, draw, and display knowledge and their interconnections $[18,19]$. The CiteSpace citation visualization and analysis software, developed by Dr. Chen Chaomei from the School of Information Science and Technology of the Drexel University, USA, has been widely and successfully applied in several studies [20,21]. CiteSpace's knowledge mapping can display the relative position of information in its domain of disciplinary knowledge; moreover, it can demonstrate the frontier of discipline research and predict the development trend of a discipline. As such, it is widely applied in many fields such as information science, library science, information and knowledge dissemination, economics, and sociology [22].

CiteSpace relies on the coword analysis and the cocitation functions to display research hotspots and frontier issues. Coword analysis was first proposed by Callon, a French bibliometrician. It is usually developed as follows. First, the number of occurrences of a group of words in the same document in pairs is counted. Then, a cluster analysis is performed on these words to reflect the close and distant relationships between these words [23]. Cocitation analysis was first proposed by Small. It focuses on a specific set of documents, representative of a discipline, as the objects of analysis, and through multivariate statistical analysis methods such as clustering analysis and multidimensional scaling and with the help of computers, it may simplify the complex cocitation network of relationships among numerous objects of analysis into the relationships between some classifications with relatively small numbers and show them in an intuitive way [24].

2.2. Steps of CiteSpace Analysis. We used CiteSpace5.7.R1 to conduct the knowledge mapping analysis of 773 pieces of literature on the theme of "brownfield," retrieved in Web of Science and published during the period 1980-2020. The overall research framework involved the following four steps, which are shown in Figure 1.

Step 1. Determination of the literature retrieval tool.

Web of Science (WOS) is the largest and most comprehensive academic information resource in the world. Web of Science is an online subscription-based scientific citation indexing service. It gives access to multiple databases that reference cross-disciplinary research, allowing for in-depth exploration of specialized subfields within an academic or scientific discipline. In this study, Web of Science was used as a literature retrieval tool. Because of the wide range of studies on brownfield, it was difficult to collect all existing studies. Luckily, Web of Science not only can provide users with access to relatively comprehensive academic literature with a uniform format but also has good compatibility with CiteSpace.

Step 2. Determination of the keywords and the time range for the retrieval.

The term "brownfield" first appeared in the CERCLA, passed by the United States Congress in 1980. Therefore, the time limit was set to cover the period of "1980-2020." The Web of Science core database was queried with the keyword "brownfield," and the category was limited to "article." In this way, a total of 773 scientific articles were obtained on June 23, 2020.

Step 3. Data export.

We exported the 773 articles retrieved and selected the "Save as another file format" option. We selected the "Full record and cited reference" option and exported the files in a plain text format. 


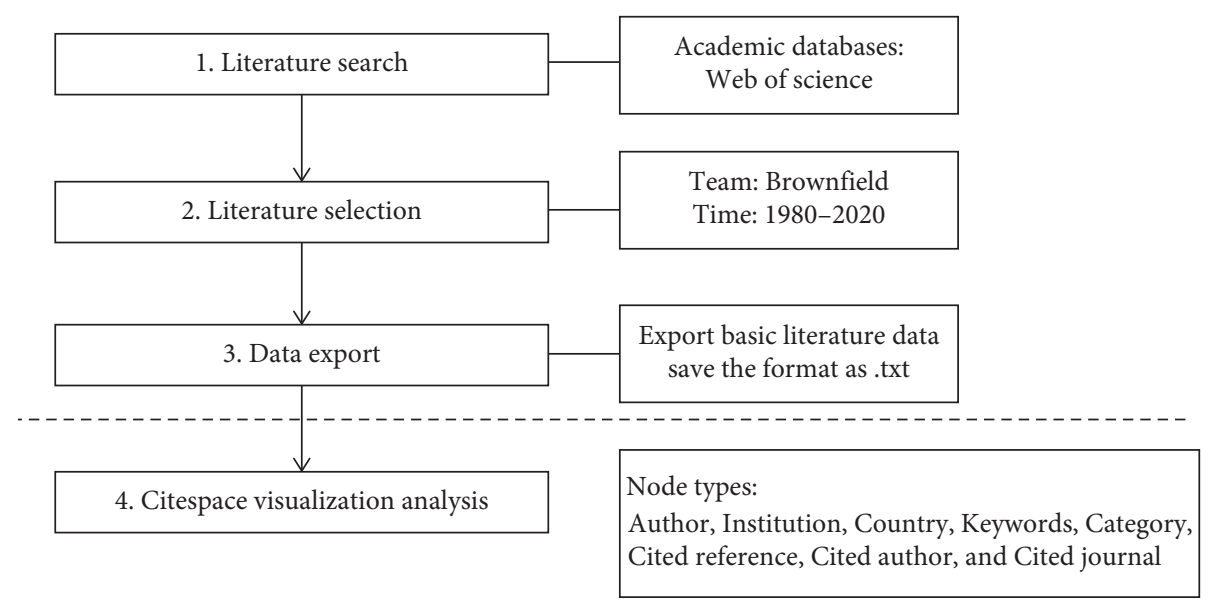

FIgURE 1: Flow diagram of the bibliometric analysis performed with CiteSpace.

Step 4. Knowledge mapping analysis using CiteSpace. A visual analysis of the network mapping was performed on the 773 texts obtained through the search described above. First, opening the CiteSpace software, we imported the document data; second, we set the time slicing as 1980-2020; then, we selected the Node Types to be analyzed, such as country, institution, author, category, keywords, cited references, cited author, and cited journal. These techniques have been employed by previous studies and generated excellent research results [25].

\section{Results}

In this paper, the research on brownfield was summarized and organized mainly through the analysis of the number of publications, the coword analysis, the coauthor analysis, the cocitation analysis, and the cluster analysis. The analysis of the number of papers published allowed assessing the development process of brownfield research. The coword analysis allowed identifying and summarizing the frontier hotspots and keywords in brownfield research. The coauthor analysis allowed assessing the academic impact of authors, countries, and institutions in brownfield research. The cocitation analysis allowed extracting and summarizing the scientific structure and the development trend of brownfield. Finally, the cluster analysis can make an efficient classification of abundant research data and contribute to forming objective-based research clusters [26].

3.1. Number of Publications. Figure 2 shows the annual publications from 1980 to June 23, 2020. In 1980, Rosman et al. [27] published the first article entitled "Isotope composition of $\mathrm{Cd}, \mathrm{Ca}$ and $\mathrm{Mg}$ in the brownfield chondrite." No articles were published in 1981-1993. After that, a total of 21 articles were published between 1994 and 1999. The year of 2000 is the watershed of brownfield research. After 2000, the amount of brownfield-related publications increased rapidly. Between 2000 and 2020, a total of 751 articles were published, accounting for $97.15 \%$ of the total number of publications. This means that more and more scholars recognized the importance of this research field.

\subsection{Coword Analysis}

3.2.1. Network of Cooccurring Subject Categories. Through analysis, it was found that the subject categories on brownfield research mainly involve Environmental Sciences and Ecology (427 publications), Environmental Sciences (280 publications), Engineering (166 publications), Environmental Studies (162 publications), Urban Studies (111 publications), Public Administration (86 publications), Regional and Urban Planning (73 publications), Geography (67 publications), and Business and Economics (62 publications). The Environmental Sciences and Ecology subject mainly focuses on aspects such as brownfield pollution measurement, soil remediation planning, plot clearing, and soil remediation. The Engineering subject mainly focuses on both the preparation and construction stages of brownfield regeneration projects. Urban Planning mainly focuses on aspects such as the selection of the transformation direction in the decision-making stage of a project and the design of land layout in the project designing stage. Geography mainly focuses on aspects such as spatial attributes and regional differences of brownfield, identifying brownfields, and establishment of a GIS brownfield database.

3.2.2. Network of Cooccurring Keywords. The keyword analysis represents the research hotspots of a discipline. Every node represents a keyword. Larger nodes indicate keywords that attract more attention. The connection lines between nodes represent the cocitation relationships between keywords [28]. The high-frequency keywords mainly include "brownfield"(195), "heavy metal"(75), "redevelopment"(67), "regeneration"(52), "sustainability"(50), “remediation"(49), "city"(49), "soil"(44), "brownfield redevelopment"(39), and "management" (35). As shown in Table 1, brownfield research focuses on understanding and controlling brownfields, while later ones focus on brownfield development and management. 


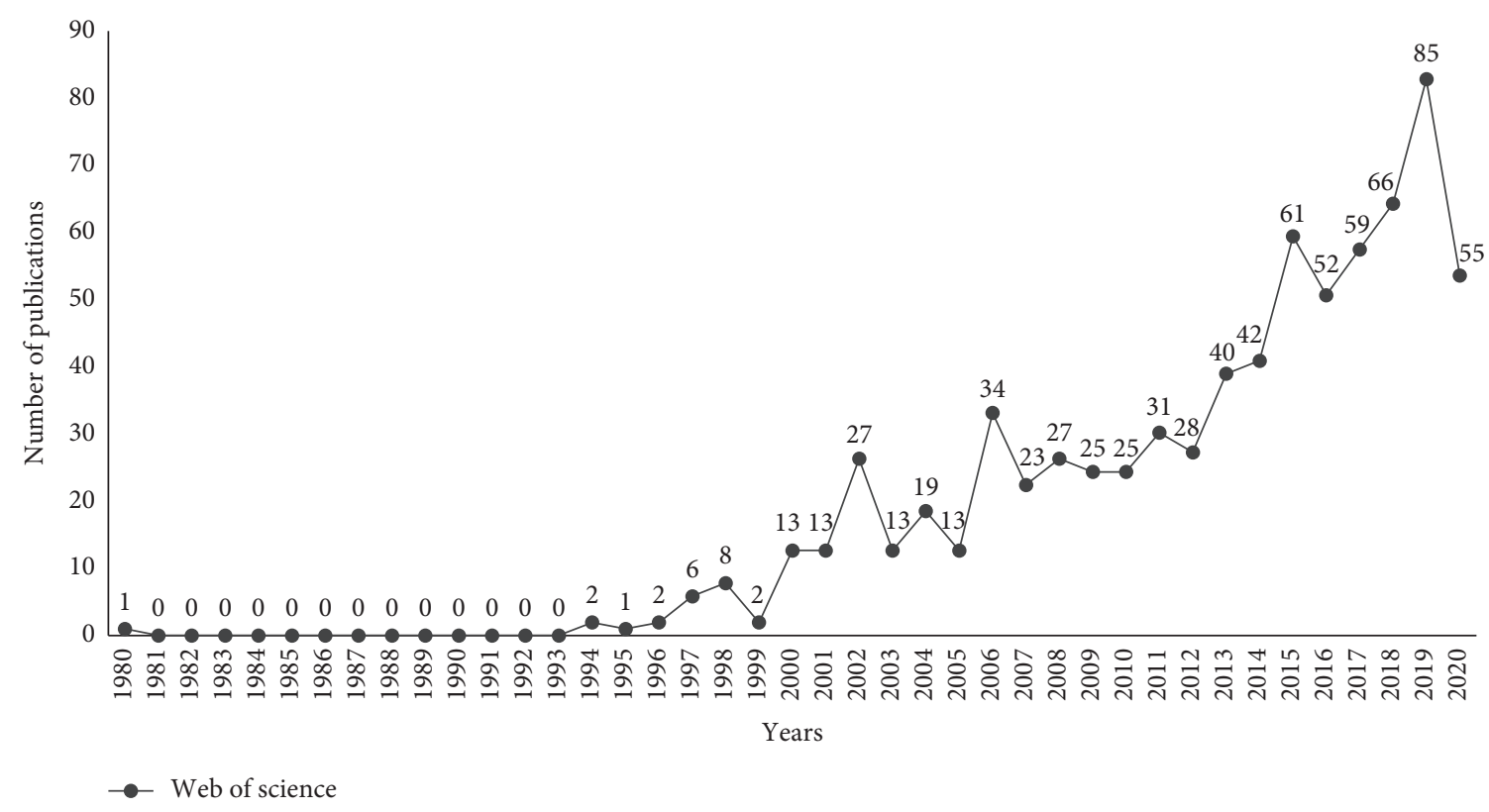

FIGURE 2: Number of publications on brownfield in the WOS core collection (1980-2020).

TABLE 1: Evolution trends of the top 10 keywords in brownfield research.

\begin{tabular}{lcc}
\hline No. & Count & Keywords \\
\hline 1 & 195 & Brownfield \\
2 & 75 & Heavy metal \\
3 & 67 & Redevelopment \\
4 & 52 & Regeneration \\
5 & 50 & Sustainability \\
6 & 49 & Remediation \\
7 & 49 & City \\
8 & 44 & Soil \\
9 & 39 & Brownfield redevelopment \\
10 & 35 & Management \\
\hline
\end{tabular}

3.2.3. Network of Cooccurring Hotspots. The Timeline tool in the CiteSpace software can show the time span of development and evolution, as well as the research process of each cluster. As shown in Figure 3, hotspots were not developed during the period of 1980 and 1995, because only 4 articles were published during that period. The research hotspots between 1996 and 2001 include "Canada," "redevelopment" [29], "brownfield," "management," "land use," "urban neighborhood," "soil," "contamination," and "Europe." Between 2002 and 2007 include "city," "biodiversity," "brownfield regeneration," "green space," "policy," "community," "design," "land," "bioremediation," "heavy metal" [30], "plant," "sustainability," "incentive," and "toxicity." The research hotspots between 2008 and 2013 include "regeneration," "remediation," "arsenic," "bioaccessibility," "phytoremediation model," "risk assessment," "system," "dynamics," "Czech Republic," "environment," "preference," "revitalization," and "polycyclic aromatic hydrocarbon" [31]. The research hotspots between 2014 and 2020 include "pollution," "China," "support system," "tool," "region," "spatial pattern," "sustainable," "health risk," "space," "optimization," "construction," "politics," “publicprivate partnership," "gulf," "health," and "developing country." In general, the research hotspots mainly include soil remediation, brownfield redevelopment, and urban studies. Research on soil remediation mainly includes heavy metal, PAH, and $\mathrm{Zn}$, as well as research on bioremediation and phytoremediation technologies for brownfield management. Brownfield redevelopment includes aspects such as risk assessment, decision support systems, city, management, and impact assessment. Urban studies aspects include the relationship between brownfields and environment, population, urbanization, and gentrification; the research objects include Europe, China, and Czech Republic. Brownfield redevelopment is implemented on the premise of sustainable development, giving appropriate consideration to stakeholders and paying attention to various risks involved in the process.

\subsection{Coauthor Analysis}

3.3.1. Coauthorship Network. The size of the nodes is positively correlated with the number of publications; the connection lines between authors represent the cooperative relationships between them. As shown in Table 2, the scholar with the largest number of published articles is Martinat et al. (burst strength $=4.83$ ) [32], followed by Zhu (burst strength $=4.45$ ) and by Klusacek, Gallego, Critto, Hipel, Gallaher, Frantal, and Pizzol. Among them, the team of Martinat has formed a strong cooperation network, including scholars such as Klusacek, Pizzol, Frantal, and Critto. The team of Zhu includes scholars such as Qingye Han, Ahmad, and Hongli Lin. The team of Hipel includes scholars such as Kilgour, Wang, and Chen. The team of Gallagher includes Pechmann, Grabosky, and so on. From the perspective of time, the team of Gallaher concentrated on 


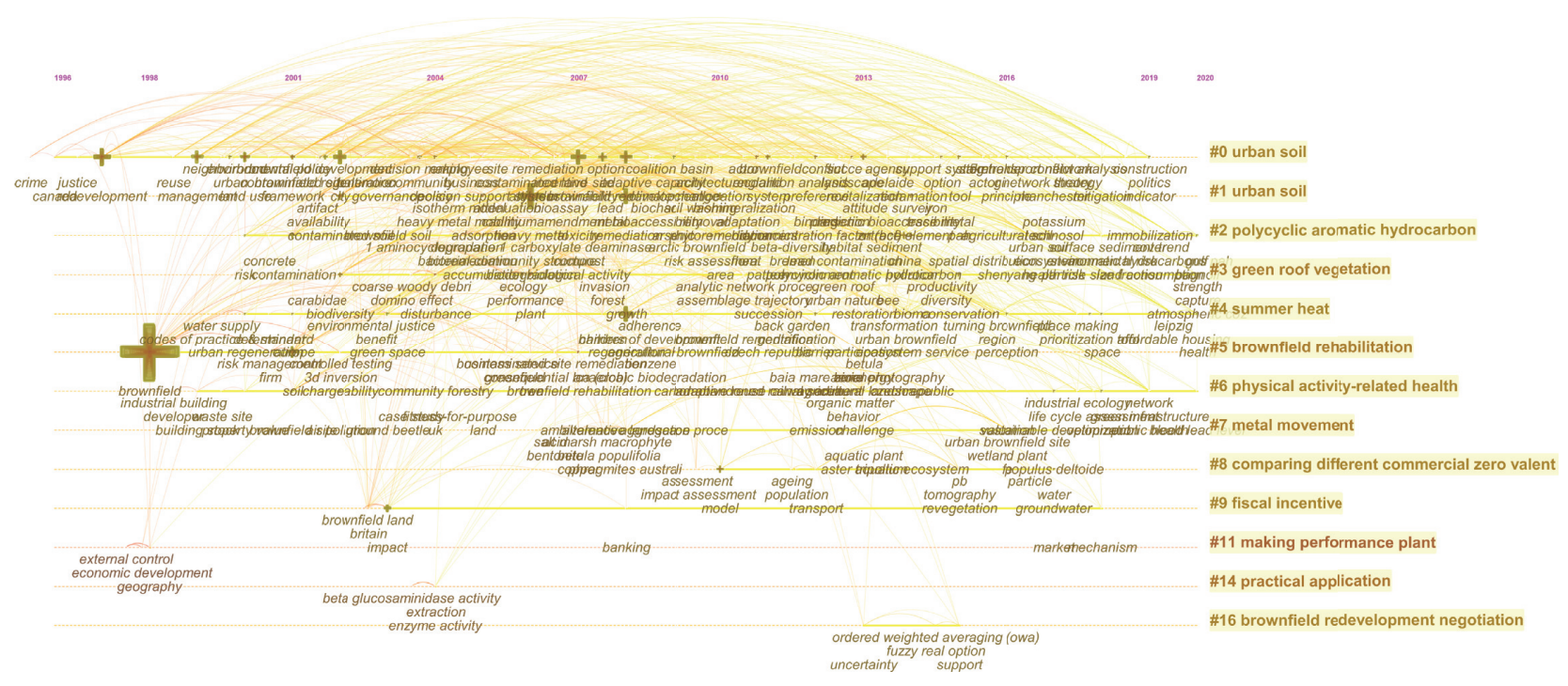

FIGURE 3: Evolution trends of brownfield research (1998-2020).

TABLE 2: Top 10 most productive authors.

\begin{tabular}{|c|c|c|c|c|c|}
\hline Author & Institution & Country & Project & Count & Year \\
\hline Martinat & Cardiff University & UK & Geography and Planning & 13 & 2014 \\
\hline Zhu & Northwestern Polytechnical University & China & Management & 9 & 2018 \\
\hline Klusacek & Mendel University Brno & Czech Republic & Environmental Geography & 9 & 2014 \\
\hline Gallego & Oviedo University & Spain & Environmental Engineering & 9 & 2015 \\
\hline Critto & Università Ca' Foscari Venezia & Italy & Environmental Pollution & 8 & 2015 \\
\hline Hipel & University of Waterloo & Canada & Management & 8 & 2009 \\
\hline Gallaher & Rutgers State University & USA & Landscape Architecture & 8 & 2008 \\
\hline Frantal & Institute of Geonics of the Czech Academy of Sciences & Czech Republic & Environmental Geography & 7 & 2014 \\
\hline Pizzol & Università Ca' Foscari Venezia & Italy & Environmental Sciences & 7 & 2016 \\
\hline Zabeo & Università Ca' Foscari Venezia & Italy & Environmental Sciences & 5 & 2016 \\
\hline
\end{tabular}

brownfield research around 2008, Hipel KW's team in 2009, Martinat's team in 2014, Gallego in 2015, Pizzol L's team in 2016, Yuming Zhu's team in 2018.

3.3.2. Network of Coauthors' Countries. The 773 reviewed studies originate from 59 different countries and regions covering six continents. All the articles with coauthors originating from different countries and regions were considered in the research origin location as shown in Figure 4 . The USA is the largest contributor to brownfield research, with a total of 201 published articles, followed by the UK, with 138 published articles, and China (74 publications), Germany (61 publications), and Italy (57 publications). 19 countries have published more than 10 articles. The top five countries (the USA, UK, China, Germany, and Italy) play leading roles in the field of brownfield research, having contributed to $68.69 \%$ of all the published articles. Moreover, it can be seen that the research on brownfield is mainly concentrated in countries with higher levels of urbanization and industrialization. With the acceleration of global urbanization, China, Spain, and the Czech Republic have gradually attached importance to issues such as environment and urban land use and conducted additional research on brownfields.

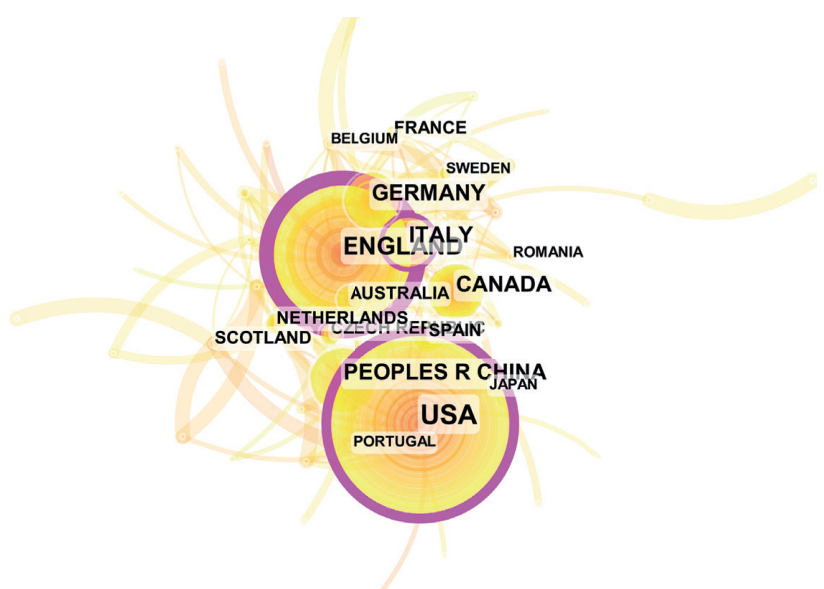

FIGURE 4: Brownfield research distribution in different countries.

3.3.3. Network of Coauthors' Institutions. Brownfield research institutions include the Rutgers State University (20 publications) in USA, the Helmholtz-Centre for Environmental Research (18 publications) in Germany, the Montclair State University (15 publications) in USA, the Liverpool John Moores University (13 publications) in UK, the Chinese Academy of Sciences (13 publications) in China, 
the University of Waterloo (11 publications) in Canada, University of Oviedo (11 publications) in Spain. Brownfield research institutions are mainly concentrated in North America and European countries and mainly in colleges and universities. Brownfield research has been accepted widely, and communication platforms and partnerships exist between different countries and institutions. Recent research also revealed variations in brownfield research between developed and developing countries. Research in developed countries focuses on brownfield redevelopment and management policies while developing countries mainly focus on the recognition and concern of brownfield, on lessons from brownfield management and redevelopment in Western countries, and on the application of landscape design and ecological restoration in brownfield reconstruction.

3.4. Cocitation Analysis. Cocitation analysis is based on the analysis of the mutual citations between documents. Articles with similarities are often cited simultaneously, and two pieces of literature (or authors) show a cocitation relationship when they are simultaneously cited by a third piece of literature (or author).

3.4.1. Document Cocitation Network. The extent to which other studies cite publications can also represent the impact of researchers on brownfield research. The document cocitation network received a total of 907 document nodes, while a total of 3,232 links were identified. Each node represents a file on brownfield research, with a label showing the author's name and the year of publication. The frequency of document cocitation was ranked from high to low. Table 3 shows the top ten authors in terms of title, journal source, year, citation frequency, burst, and so on. The author with the highest number of citations is Schädler (27), followed by Pizzol (23), Rizzo (21), Cheng (29), Rall (18), Bartke (16), Chrysochoou (16), Alker (15), Thornton (15), and Frantal (15). The author with the highest citation rate, Schädler et al. [33] from the University of Tuebingen in Germany, mainly focused on sustainable brownfield renaissance strategy and established a comprehensive assessment model for brownfield redevelopment. Pizzol et al. [34] at the University of Venice introduced the Timbre Brownfield Prioritization Tool (TBPT), a web-based solution developed to assist stakeholders to identify which brownfield sites should be preferably considered for redevelopment or for further investigation. Rizzo et al. [35] presented and discussed a participatory methodology whose research outcomes allowed creating a knowledge base for the future development of tailored and customized approaches and tools for stakeholders working in the brownfield regeneration field. Cheng et al. [36] from the Utrecht University focused on brownfield recognition methods and used data on taxes and environmental records to identify brownfield, using the Futian District of Shenzhen in China as a case study. Rall and Haase [37] from the Humboldt University in Germany paid attention to the sustainable development of brownfield and used a triangular comprehensive evaluation method and expert interviews and questionnaires to establish the assessment indicators on sustainable development, focusing on the case study of Leipzig to revitalize its declining neighborhoods. Bartke and Schwarze [38] from the Helmholtz-Zentrum für Umweltforschung provided three approaches to sustainability assessment, in order to make sound land-use decisions between new development on greenfield sites and the regeneration of brownfields. Chrysochoou et al. [39] presented an indexing scheme to screen large numbers of brownfield sites in wide areas, in order to develop initial planning strategies for fund allocation and redevelopment. Alker et al. [40] discussed the definition of "brownfield" from a multidisciplinary perspective. Thornton et al. [41] of the Oxford Brookes University presented the existing incentives at the European Union level, as well as in Germany, the UK, and France; his paper compares the differences between these measures and provides suggestions for brownfield regeneration. Frantál et al. [42] explored the spatial patterns of urban brownfields' regeneration to demonstrate the effects of brownfield location on the potential investor decisions.

3.4.2. Author Cocitation Network. According to the analysis of the author cocitation, the articles with anonymous authors are cited most frequently up to 126 times, followed by De Sousa, cited 91 times in total. De Sousa focuses on brownfield policy mechanisms, urban planning, liability for compensation, and redevelopment, mainly in America and Canada. Alker was cocited 75 times, followed by Adams (59), Thornton (52), Dixon (50), US EPA (43), and Bartsch (41). The author cocitation analysis performed with CiteSpace allowed identifying the most important research scholars in a given period of time. According to the results of this analysis, the scholars with the higher burst strength include the US EPA (burst strength=16.50), Bartsch (burst strength $=10.92$ ), Simons (burst strength $=7.41$ ), Loures (burst strength $=7.41$ ), Pizzol (burst strength =7.02), Rizzo (burst strength $=6.5$ ), and Schädler (burst strength $=6.35$ ).

3.4.3. Journal Cocitation Network. The diffusion of brownfield research studies published in journals cocitation is numerous and scattered. Therefore, Table 4 only illustrated the distribution of the journals cocitation that published at least 20 studies on brownfield. Science of the Total Environment was the journal with the highest frequency of citation in brownfield research (frequency $=202$ ), followed by the Journal of Environmental Management (frequency $=117$ ). Landscape and Urban Planning (frequency $=147$ ), Environmental Science \& Technology (frequency $=146$ ), and Journal of Environmental Planning and Management (frequency $=139$ ), and Land Use Policy $($ frequency $=130)$.

3.5. Clusters Analysis. Cluster analysis is employed to analyze the research trends and interconnections and to detect the outstanding terms and context. In addition, cluster analysis allows an efficient classification of abundant research data and can contribute to forming objective-based 
TABLE 3: The top 10 cocited documents in the document cocitation network in brownfield research.

\begin{tabular}{|c|c|c|c|c|c|c|c|c|c|}
\hline No. & Author & Title & Journal source & Year & $\begin{array}{c}\text { Cited } \\
\text { Freq }\end{array}$ & Burst & Vol. & Page & DOI \\
\hline 1 & $\begin{array}{l}\text { Schädler, Morio, } \\
\text { Bartke et al. }\end{array}$ & $\begin{array}{l}\text { Designing sustainable } \\
\text { and economically } \\
\text { attractive brownfield } \\
\text { revitalization options } \\
\text { using an integrated } \\
\text { assessment model. }\end{array}$ & $\begin{array}{c}\text { Journal of } \\
\text { Environmental } \\
\text { Management }\end{array}$ & 2011 & 27 & 5.14 & 92 & $827-837$ & $\begin{array}{c}10.1016 / \\
\text { j.jenvman.2010.10.026 }\end{array}$ \\
\hline 2 & $\begin{array}{l}\text { Pizzol, Zabeo, } \\
\text { Klusáček }\end{array}$ & $\begin{array}{l}\text { Timbre Brownfield: } \\
\text { Prioritization Tool to } \\
\text { support effective } \\
\text { brownfield } \\
\text { regeneration. }\end{array}$ & $\begin{array}{c}\text { Journal of } \\
\text { Environmental } \\
\text { Management }\end{array}$ & 2016 & 23 & 6.16 & 166 & $178-192$ & $\begin{array}{c}10.1016 / \\
\text { j.jenvman.2015.09.030 }\end{array}$ \\
\hline 3 & $\begin{array}{l}\text { Rizzo, Pesce, } \\
\text { Pizzol, et al. }\end{array}$ & $\begin{array}{c}\text { Brownfield } \\
\text { regeneration in Europe: } \\
\text { Identifying stakeholder } \\
\text { perceptions, concerns, } \\
\text { attitudes and } \\
\text { information needs. }\end{array}$ & Land Use Policy & 2015 & 21 & 5.48 & 48 & $437-453$ & $\begin{array}{c}10.1016 / \\
\text { j.landusepol.2015.06.012 }\end{array}$ \\
\hline 4 & $\begin{array}{l}\text { Cheng, } \\
\text { Geertman, } \\
\text { Kuffer, et al. }\end{array}$ & $\begin{array}{l}\text { An integrative } \\
\text { methodology to } \\
\text { improve brownfield } \\
\text { redevelopment } \\
\text { planning in Chinese } \\
\text { cities: A case study of } \\
\text { Futian, Shenzhen. }\end{array}$ & $\begin{array}{c}\text { Computers } \\
\text { Environment and } \\
\text { Urban Systems }\end{array}$ & 2011 & 20 & 0 & 35 & $388-398$ & $\begin{array}{c}10.1016 / \\
\text { j.compenvurbsys.2011.05.007 }\end{array}$ \\
\hline 5 & Rall, Haase & $\begin{array}{l}\text { Creative intervention } \\
\text { in a dynamic city: A } \\
\text { sustainability } \\
\text { assessment of an } \\
\text { interim use strategy for } \\
\text { brownfields in Leipzig, } \\
\text { Germany. }\end{array}$ & $\begin{array}{l}\text { Landscape and } \\
\text { Urban Planning }\end{array}$ & 2011 & 18 & 4.78 & 100 & 189-201 & $\begin{array}{c}10.1016 / \\
\text { j.landurbplan.2010.12.004 }\end{array}$ \\
\hline 6 & Bartke, Schwarze & $\begin{array}{l}\text { No perfect tools: Trade- } \\
\text { offs of sustainability } \\
\text { principles and user } \\
\text { requirements in } \\
\text { designing support tools } \\
\text { for land-use decisions } \\
\text { between greenfields } \\
\text { and brownfields. }\end{array}$ & $\begin{array}{c}\text { Journal of } \\
\text { Environmental } \\
\text { Management }\end{array}$ & 2015 & 16 & 5.23 & 153 & $11-24$ & $\begin{array}{c}10.1016 / \\
\text { j.jenvman.2015.01.040 }\end{array}$ \\
\hline 7 & $\begin{array}{l}\text { Chrysochooua, } \\
\text { Browna, Dahal, } \\
\text { et al. }\end{array}$ & $\begin{array}{l}\text { A GIS and indexing } \\
\text { scheme to screen } \\
\text { brownfields for area- } \\
\text { wide redevelopment } \\
\text { planning. }\end{array}$ & $\begin{array}{l}\text { Landscape and } \\
\text { Urban Planning }\end{array}$ & 2012 & 16 & 0 & 105 & $187-198$ & $\begin{array}{c}10.1016 / \\
\text { j.landurbplan.2011.12.010 }\end{array}$ \\
\hline 8 & $\begin{array}{l}\text { Alker, Joy, } \\
\text { Roberts, et al. }\end{array}$ & $\begin{array}{l}\text { The Definition of } \\
\text { Brownfield. }\end{array}$ & $\begin{array}{c}\text { Journal of } \\
\text { Environmental } \\
\text { Planning and } \\
\text { Management }\end{array}$ & 2000 & 15 & 8.43 & 43 & $49-69$ & $10.1080 / 09640560010766$ \\
\hline 9 & $\begin{array}{l}\text { Thornton, Franz, } \\
\text { Edwards, et al. }\end{array}$ & $\begin{array}{l}\text { The challenge of } \\
\text { sustainability: } \\
\text { Incentives for } \\
\text { brownfield } \\
\text { regeneration in Europe. }\end{array}$ & $\begin{array}{l}\text { Environmental } \\
\text { Science \& Policy }\end{array}$ & 2007 & 15 & 4.9 & 10 & $116-134$ & 10.1016/j.envsci.2006.08.008 \\
\hline
\end{tabular}


TABLE 3: Continued.

\begin{tabular}{|c|c|c|c|c|c|c|c|c|c|}
\hline No. & Author & Title & Journal source & Year & $\begin{array}{c}\text { Cited } \\
\text { Freq }\end{array}$ & Burst & Vol. & Page & DOI \\
\hline 10 & $\begin{array}{l}\text { Frantal, Greer- } \\
\text { Wootten, } \\
\text { Klusáček, et al. }\end{array}$ & $\begin{array}{l}\text { Exploring spatial } \\
\text { patterns of urban } \\
\text { brownfields } \\
\text { regeneration: The case } \\
\text { of Brno, Czech } \\
\text { Republic. }\end{array}$ & Cities & 2015 & 15 & 4.9 & 44 & $9-18$ & 10.1016/j.cities.2014.12.007 \\
\hline
\end{tabular}

TABLE 4: The top 20 journals in brownfield research, according to the 773 publications.

\begin{tabular}{lccc}
\hline No. & Freq. & Year & Source \\
\hline 1 & 202 & 2003 & Science of the Total Environment \\
2 & 177 & 2002 & Journal of Environmental Management \\
3 & 147 & 2006 & Landscape and Urban Planning \\
4 & 146 & 2002 & Environmental Science \& Technology \\
5 & 140 & 2002 & Environmental Pollution \\
6 & 139 & 2002 & Land Use Policy \\
7 & 130 & 2004 & Urban Studies \\
8 & 124 & 2001 & Chemosphere \\
9 & 117 & 2005 & Journal of Environmental Planning and Management \\
10 & 99 & 2005 & Environment and Planning A \\
11 & 93 & 2006 & Environment International \\
12 & 82 & 2007 & Thesis \\
13 & 79 & 2015 & Water Air and Soil Pollution \\
14 & 77 & 2008 & Journal of Cleaner Production \\
15 & 76 & 2007 & Environmental Science \& Policy \\
16 & 70 & 2008 & Journal of Environmental Quality \\
17 & 69 & 2010 & Science \\
18 & 69 & 2005 & Ecological Economics \\
19 & 69 & 2009 & \\
20 & 66 &
\end{tabular}

research clusters. The largest 11 clusters are shown in Figure 5 and briefly summarized below.

Cluster \#0 "Czech Republic" is the largest cluster. Since 2002, the issue of brownfield in the Czech Republic has attracted the attention of several scholars focusing on the evaluation, redevelopment patterns, and the impact of public administration on brownfield redevelopment. The main topics of research in this cluster are brownfield evaluation applied a multicriteria genetic algorithm [43], multidisciplinary spatial optimization algorithms [44], and prioritization methodology to integrated planning and assessment of brownfield redevelopment options. Based on a questionnaire survey, Navratil et al. [45] obtained residents' preferences for brownfield redevelopment and found that future brownfield uses such as culture/sport and children's parks are the most popular options. Klusáček et al. [46] assumed that the public administration at the regional and municipal level plays an active role in devising strategies to attract investors for brownfield redevelopment.

Cluster \#1 "International context" focuses on brownfield redevelopment in an international context. De Sousa [47] examined the types of policy measures that are currently being adopted in Canada to overcome variability in regulatory processes, lack of information on soil quality, impractical cleanup standards, fear of liability, and limited funding resources for cleanups. De Sousa [48] described brownfield redevelopment patterns in the former "City of Toronto" during the 1990s and future prospects. Bacot and O’Dell [49] established indicators to evaluate brownfield redevelopment.

Cluster \#2 "Greenwaste compost mulch" focuses on the effect of green compost mulch on the treatment of contaminated soil [50].

Cluster \#3 “Brownfield residential development" focuses on the relationship between brownfields and gentrification, housing prices [51], and economic growth [52]. Baeing and Wong [53] examined the impact of residential brownfield development on the most deprived urban areas and drew conclusions about the effectiveness of brownfield development in tackling deprivation. Mashayekh et al. [54] demonstrated that residential brownfield developments reduce the vehicle kilometers traveled by $52 \%$ compared to conventional greenfield developments.

In Cluster \#4 “Metal distribution," Salisbury et al. [55] analyzed soil data in a spontaneously vegetated urban brownfield contaminated with $\mathrm{As}, \mathrm{Cr}, \mathrm{Cu}, \mathrm{Pb}$, and $\mathrm{Zn}$. Using synchrotron X-ray microfluorescence, Feng et al. [56] investigated the distribution of $\mathrm{Br}, \mathrm{Ca}, \mathrm{Cl}, \mathrm{Cr}, \mathrm{Cu}, \mathrm{K}, \mathrm{Fe}, \mathrm{Mn}$, $\mathrm{Pb}, \mathrm{Ti}, \mathrm{V}$, and $\mathrm{Zn}$ in the root system of Phragmites australis and the function of Fe nanoparticles in scavenging metals in the root epidermis. 


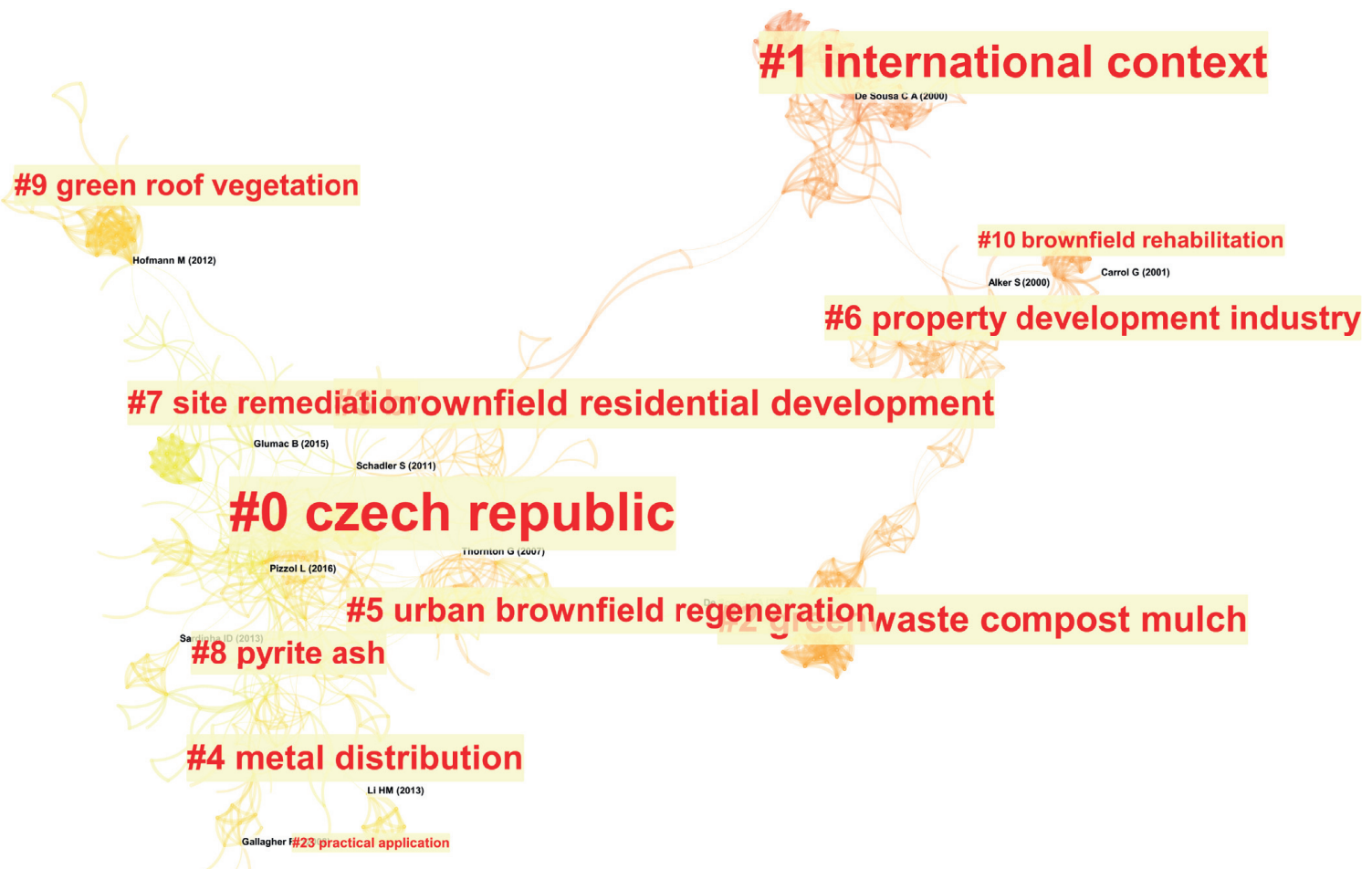

FiguRe 5: Document cocitation clusters of brownfields.

In Cluster \#5 "Urban brownfield regeneration," Dixon et al. [57] compared the approaches for bringing back hardcore brownfield sites into use in England and Japan by focusing on ten case studies in Manchester and Osaka, using an "agency"-based framework. Glumac et al. [58] provided a valid representation of brownfield redevelopment negotiation within the Dutch institutional-economic context. BenDor et al. [59] explored barriers to brownfield redevelopment, including fear of liability, regulatory concerns, and uncertain cleanup standards and funding mechanisms. Chen and Ma [60] developed small-scale risk maps to determine the relationship between population risk (PR) and damaged land value (DLV) to facilitate flexible land reutilization plans.

In relation to Cluster \#6 "Property development industry," the UK property development industry is a key player in brownfield regeneration projects. Based on structured interviews with a variety of stakeholders, including developers, planners, consultants, and community representatives, Dixon [61] highlighted emerging best practices and related policy implications. Dixon and Adams [62] traced the emergence of the brownfield regeneration policy agenda across the UK and examined how the Barker review connects with this brownfield policy focus.

In Cluster \#7 "Site remediation," Ahmad et al. [63] aimed to identify significant strategies to promote brownfield redevelopment in developing countries focusing on the case of Pakistan. Zhong et al. [64] introduced the concept and main features of brownfield greening, firstly depicting its costs and benefits. Zhang et al. [65] extended the standard theory of the planned behavior model by including trust and risk perception to determine which factors influence real estate projects developed on industrial brownfields purchase intention, providing a basis for policy formulation and redevelopment strategies. Based on the Graph Model of Conflict Resolution, Han et al. [66] developed a two-stage decision framework to reveal the essence of brownfield incidents and facilitate the resolution of brownfield conflicts caused by the incidents.

In relation to Cluster \#8 "Pyrite ash," soil remediation is an essential step for the redevelopment of brownfields. This topic focuses on the removal of potentially toxic elements from soil contaminated with pyrite ash [67]. Boente et al. [68] conducted a feasibility study of physical soil washing techniques to separate potentially toxic elements, such as As, $\mathrm{Cu}, \mathrm{Hg}, \mathrm{Pb}$, and $\mathrm{Sb}$, in a brownfield affected by pyrite ash disposal.

In relation to cluster \#9 "Green roof vegetation," extensive green roofs are becoming a popular tool, as they have the potential to address several environmental problems associated with urbanization and can be used as mitigation for habitats lost at ground level. Brown roofs (i.e., a type of green roof) can be used to mitigate the loss of brownfield habitat $[69,70]$.

In Cluster \#10 "Brownfield rehabilitation," Lesage et al. [71] evaluated the environmental attributes and consequences of a "rehabilitation for residential redevelopment" scenario, which involves "dig and dump" remediation, infrastructure material recycling, and site backfilling.

Based on these clusters, the articles published were summarized as follows: (1) brownfield redevelopment strategy; (2) brownfield redevelopment evaluation; (3) brownfield reuse impacts; (4) soil remediation; and (5) urban brownfield. These topics represent a wide coverage in 


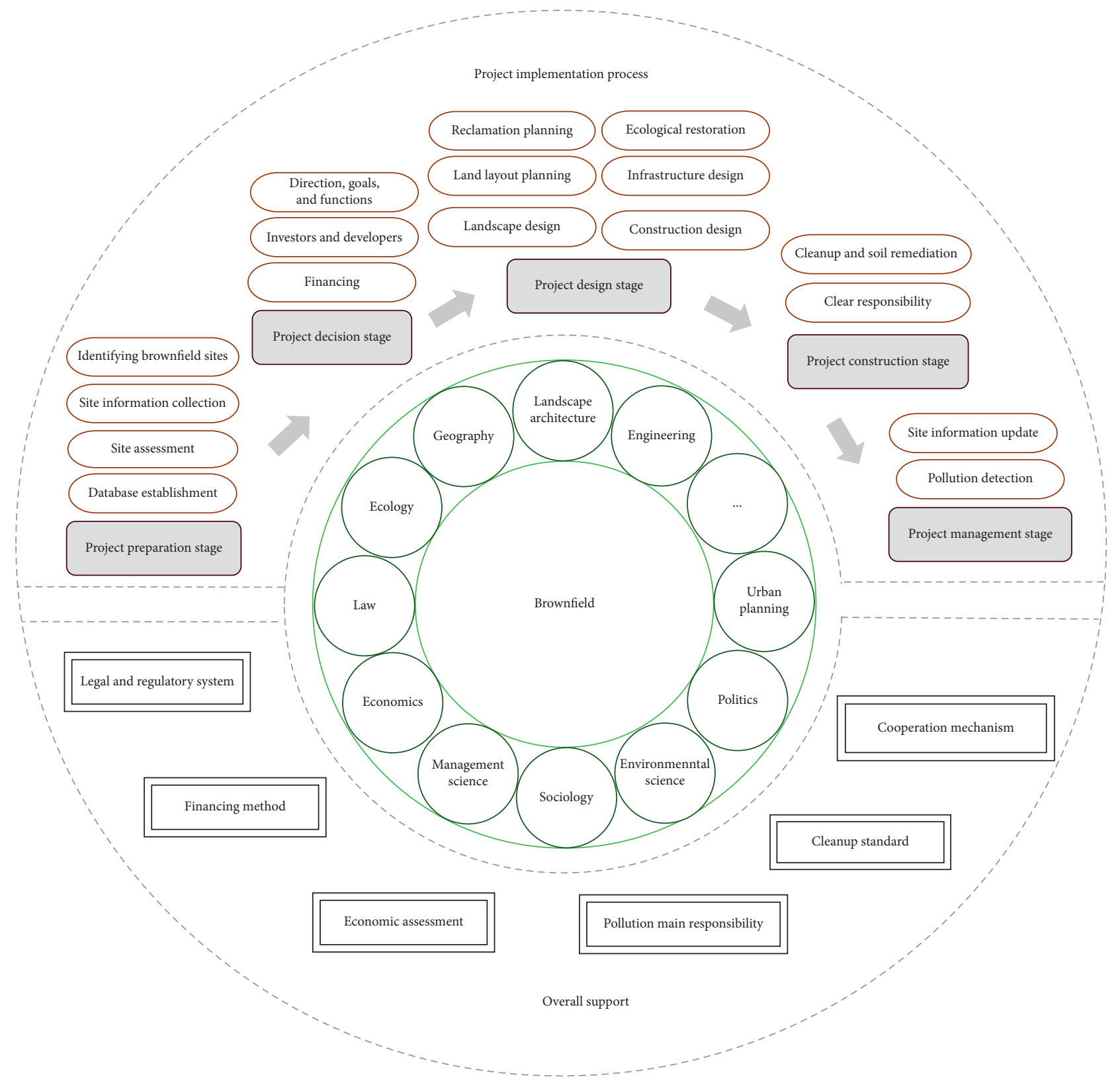

FIgURE 6: A framework for multidisciplinary integration on brownfield.

terms of modeling methods, urban studies, political systems, and cases addressing different countries.

\section{Research Framework}

4.1. A Multidisciplinary Framework of Brownfield. Through the analysis presented above in Section 3, we can find that brownfield is the focus of new urbanization and ecosystem protection and restoration. The formation, evolution, and renewal of urban brownfields is a dynamic and complex system. At present, brownfield research is scattered in many disciplines such as Geography, Economics and Management, and Urban Planning, there are few interactions among various fields, and there is a lack of systematic research on multidisciplinary. It is imperative to establish a multidisciplinary framework for the study of brownfield through multiangle analysis and empirical tests.

Each discipline plays a dominant role in different fields of brownfield research and in different stages of brownfield regeneration. At the same time, they cooperate with each other as a whole to form a cross-integration framework, as shown in Figure 6. Specifically, Urban Planning in brownfield regeneration mainly focuses on aspects such as the selection of the direction of transformation in the decision-making stage of a project and the design of land layout in the project designing stage. Environmental Engineering focuses on both the preparatory and the construction stages of brownfield regeneration projects, as well as on aspects such as brownfield pollution measurement, soil remediation planning, plot clearing and soil remediation, 
and potential contamination detection. Based on the existing research foundations of brownfield landscape planning and design, Landscape Architecture tries to make a breakthrough in the cross-research field of brownfield regeneration. Sociology focuses on a balanced study of the interests of the government, enterprises, and residents in the decisionmaking stage of a brownfield project. Geography targets the project preparation, decision-making, and design stages of brownfield reconstruction, focusing on aspects such as spatial perspective and database construction. Economics, Management Science, Politics, Law, and other disciplines are involved in the whole process of brownfield regeneration; they focus on aspects such as financing modes, economic assessment of brownfields, responsibility of pollution, establishment of a system of laws and regulations, establishment of standards for brownfield clearing, assessment and monitoring systems, and multisectoral cooperation mechanisms. For example, when an abandoned factory is redeveloped, in the preparation stage of the project, Geography can identify brownfields and establish an information database, and Environmental Engineering can determine the degree of soil pollution within the scope of the factory and formulate a soil remediation plan, while Economics can evaluate the suitability of land for redevelopment. In terms of decision-making, Urban Planning can determine the direction and goals of factory transformation, and Management and Sociology can determine financing methods and balance the interests of multiple parties. In the design stage, Landscape Architecture can provide guidance for the overall design of the factory. In the construction and postmanagement stage, Management, Sociology, and Law can provide services such as information update, supervision and maintenance, and regulation-making.

4.2. Key Research Directions in Brownfield. In recent years, research on various aspects of brownfield has increased substantially. However, with the change of the international situation, new propositions and development space for brownfield research have been advanced. Brownfield research shows a gradual change in focus, from implementing policy guidance of simple environmental control toward performing long-term planning for full activation through comprehensive scientific means. The research perspectives have also changed from the regeneration of traditional industrial and mining waste land and soil contamination clearance to an increasing focus on aspects such as brownfield systems, man-land systems, and social-economic-ecological systems. Future research on brownfield should pay more attention to the following aspects: (i) establishing a research framework on brownfield based on multidisciplinary integration and comprehensively applying the theories and methods of Environmentology, Geography, Sociology, Ecology, Landscape, Urban Planning, Economics, Management, and many other disciplines to conduct multiangle analyses and empirical tests on the interrelation of brownfield; (ii) strengthening the establishment of comprehensive evaluation methods and index systems for brownfield redevelopment, enhancing the analytical measures of spatial attributes such as spatial agglomeration, spatial accessibility, and spatial association, and comprehensively evaluating the reuse potential and the availability of brownfield plots; (iii) conducting in-depth studies on the mode selection and the planning design for brownfield regeneration $[72,73]$, scientifically determining the utilization choice of brownfield reuse, and scientifically conducting functional orientation and specific landscape design; and (iv) paying attention to practical research on the redevelopment of typical cities and typical brownfield, extracting and summarizing the plot characteristics of various types of cities and brownfield, and proposing effective and feasible regeneration measures to promote the sustainable development of cities.

\section{Conclusions}

Brownfield research is a hot topic in current urban planning, land economy, and public policy, as well as an important issue of concern in urban economic transformation and urban renewal in recent years. In this study, we summarized the overall situation of brownfield research through scientometric methods, analyzing the progress and revealing the development trends of brownfield research, which will help researchers determine future research directions and partners. Based on the 773 articles on the theme of brownfield published from 1980 to 2020 and through a visual analysis performed using CiteSpace, the following conclusions are drawn:

(i) Brownfield research has recently become a hot topic in environment and urbanization studies, with the number of published articles on the theme of brownfield showing an increasing trend on a yearly basis.

(ii) The results of the coword analysis show that brownfield research mainly involves the disciplines of Environmental Science and Ecology and that the main keywords on brownfield include "brownfield," "heavy metal," "redevelopment," "regeneration," and "sustainability." In general, the research hotspots mainly include soil remediation, brownfield redevelopment, and urban studies.

(iii) The results of the coauthor analysis show that Martinat, Zhu, Klusacek, and Gallego are the main research authors. The research scholars are mostly based in countries with a higher level of urbanization and industrialization, such as the USA, the UK, China, Germany, and Italy. The main research institutions include the Rutgers State University, the Helmholtz-Centre for Environmental Research, the Montclair State University, the Liverpool John Moores University, and the Chinese Academy of Sciences.

(iv) According to the results of the cocitation analysis, the articles published by Schädler, Pizzol, Rizzo, Cheng, and other scholars are the most influential in academic circles. De SCA, Alker, Adams, 
Thornton, and Dixon have made the greatest contribution to brownfield, and their influence is the most prominent. Articles on brownfield have mostly been published in Science of the Total Environment, Journal of Environmental Management, Landscape and Urban Planning, Environmental Science \& Technology, and so on.

(v) The results of the cluster analysis show that brownfield redevelopment strategy, brownfield redevelopment evaluation, brownfield reuse impacts, soil remediation, and urban brownfield are hot topics and emerging trends. These topics represent a wide coverage in terms of modeling methods, urban studies, political systems, and cases addressing different countries.

(vi) This paper establishes a multidisciplinary framework for brownfield research that integrates Environmental Science, Geography, Sociology, Ecology, Landscape Architecture, Urban Planning, Economics, Management, and other disciplines.

(vii) The future key research directions on brownfield should pay more attention to establishing a research framework on brownfield, strengthening the establishment of comprehensive evaluation methods for brownfield redevelopment, conducting in-depth studies on the mode selection and the planning design for brownfield regeneration, and paying attention to practical research on the redevelopment of typical cities and typical brownfield.

This study is preliminary work and has provided valuable information related to the research field of brownfield through bibliometric methods. However, some limitations were observed. First, Web of Science may cover only a limited number of articles. Multisource searching and a cross-comparison among different databases would be more convincing. Second, although we have identified the main research topics and their evolution, this paper does not analyze the brownfield identification methods, risk assessment methods, and brownfield reconstruction strategies. Future studies may continue to obtain deeper insights into different research themes.

\section{Data Availability}

The data used to support the findings of this study are available from the corresponding author upon request.

\section{Conflicts of Interest}

There are no conflicts of interest to declare.

\section{Acknowledgments}

This work was supported by the National Social Science Fund of China (no. 17BJL051); the National Natural Science Foundation of China (nos. 41630749 and 41301169); Fundamental Research Funds for the Central Universities (nos.
1709103 and 2412020FZ001); and Humanities and Social Sciences Planning Project of Jilin Provincial Department of Education (no. JJKH20181068SK).

\section{References}

[1] K. R. Yount, "What are brownfields? Finding a conceptual definition," Environmental Practice, vol. 5, no. 1, pp. 25-33, 2003.

[2] Timbre, "Brownfield definition," 2011, http://www.timbreproject.eu/en/brownfield.html.

[3] T. J. Swickard, "Regulatory incentives to promote private sector brownfield remediation and reuse," Soil and Sediment Contamination: An International Journal, vol. 17, no. 2, pp. 121-136, 2008.

[4] L. Mccarthy, "The brownfield dual land-use policy challenge: reducing barriers to private redevelopment while connecting reuse to broader community goals," Land Use Policy, vol. 19, no. 4, pp. 287-296, 2002.

[5] M. R. Thomas, "A GIS-based decision support system for brownfield redevelopment," Landscape and Urban Planning, vol. 58, no. 1, pp. 7-23, 2002.

[6] A. Alberini, A. Longo, S. Tonin, F. Trombetta, and M. Turvani, "The role of liability, regulation and economic incentives in brownfield remediation and redevelopment: evidence from surveys of developers," Regional Science and Urban Economics, vol. 35, no. 4, pp. 327-351, 2005.

[7] C. E. Burnham-Howard, "Building on brownfields: predicted effects of new liability protections for prospective purchasers and an exploration of other redevelopment incentives," Journal of Professional Issues in Engineering Education and Practice, vol. 130, no. 3, pp. 212-225, 2004.

[8] W. Ren, Y. Geng, Z. Ma, L. Sun, B. Xue, and T. Fujita, "Reconsidering brownfield redevelopment strategy in China's old industrial zone: a health risk assessment of heavy metal contamination," Environmental Science and Pollution Research, vol. 22, no. 4, pp. 2765-2775, 2014.

[9] T. L. Green, "Evaluating predictors for brownfield redevelopment," Land Use Policy, vol. 73, pp. 299-319, 2018.

[10] C. A. De Sousa, "Turning brownfields into green space in the city of Toronto," Landscape and Urban Planning, vol. 62, no. 4, pp. 181-198, 2003.

[11] D. Adams, C. De Sousa, and S. Tiesdell, "Brownfield development: a comparison of North American and British approaches," Urban Studies, vol. 47, no. 1, pp. 75-104, 2010.

[12] H. Kovacs and K. Szemmelveisz, "Disposal options for polluted plants grown on heavy metal contaminated brownfield lands-a review," Chemosphere, vol. 166, pp. 8-20, 2017.

[13] M. Keely, K. Brittany, and B. Jenifer, "How clean is clean: a review of the social science of environmental cleanups," Environmental Research Letters, vol. 13, no. 8, p. 83002, 2018.

[14] Y. Song, N. Kirkwood, Č. Maksimović et al., "Nature based solutions for contaminated land remediation and brownfield redevelopment in cities: a review," Science of The Total Environment, vol. 663, pp. 568-579, 2019.

[15] D. Oudes and S. Stremke, "Climate adaptation, urban regeneration and brownfield reclamation: a literature review on landscape quality in large-scale transformation projects," Landscape Research, vol. 45, no. 7, 2020.

[16] J. Ameller, J. D. Rinaudo, and C. Merly, "The contribution of economic science to brownfield redevelopment: a review," Integrated Environmental Assessment and Management, vol. 16, no. 2, pp. 184-196, 2019. 
[17] H. Lin, N. Ahmad, Q. Han, and Q. Y. Han, "A scientometric analysis and visualization of global research on brownfields," Environmental Science and Pollution Research, vol. 26, no. 17, pp. 17666-17684, 2019.

[18] X. Li and H. Li, "A visual analysis of research on information security risk by using CiteSpace," IEEE Access, vol. 6, pp. 63243-63257, 2018.

[19] R. M. Shiffrin and K. Borner, "Mapping knowledge domains," Proceedings of the National Academy of Sciences, vol. 101, no. Supplement 1, pp. 5183-5185, 2004.

[20] J. Hou, X. Yang, and C. Chen, "Emerging trends and new developments in information science: a document co-citation analysis (2009-2016)," Scientometrics, vol. 115, no. 2, pp. 869-892, 2018.

[21] C. Chen, F. Ibekwe-Sanjuan, and J. Hou, "The structure and dynamics of cocitation clusters: a multiple-perspective cocitation analysis," Journal of the American Society for Information Science and Technology, vol. 61, no. 7, pp. 1386-1409, 2010 .

[22] Z. Y. Liu, X. W. Wang, and C. Chen, "Scientific knowledge mapping and its application in scientific and technological information field," Digital Library Forum, vol. 10, pp. 14-34, 2009.

[23] M. Callon, J. P. Courtial, and F. Laville, "Co-word analysis as a tool for describing the network of interactions between basic and technological research: the case of polymer chemsitry," Scientometrics, vol. 22, no. 1, pp. 155-205, 1991.

[24] H. Y. Geng and X. T. Xiao, "The research progress and trends of co citation analysis in foreign countries," Journal of Information, vol. 25, no. 12, pp. 68-72, 2006.

[25] T. O. Olawumi and D. W. M. Chan, "A scientometric review of global research on sustainability and sustainable development," Journal of Cleaner Production, vol. 183, pp. 231-250, 2018.

[26] M. J. Cobo, A. G. López-Herrera, E. Herrera-Viedma, and F. Herrera, "Science mapping software tools: review, analysis, and cooperative study among tools," Journal of the American Society for Information Science and Technology, vol. 62, no. 7, pp. 1382-1402, 2011.

[27] K. J. R. Rosman, I. L. Barnes, L. J. Moore, and J. W. Gramlich, "Isotope composition of $\mathrm{Cd}, \mathrm{Ca}$ and $\mathrm{Mg}$ in the brownfield chondrite," Geochemical Journal, vol. 14, pp. 267-277, 1980.

[28] Z. M. Li, S. Y. Xu, and L. M. Yao, "A systematic literature mining of sponge city: trends, foci and challenges standing ahead," Sustainability, vol. 10, no. 4, p. 1182, 2018.

[29] A. Longo and D. Campbell, "The determinants of brownfields redevelopment in England," Environmental and Resource Economics, vol. 67, no. 2, pp. 261-283, 2017.

[30] C. Dahlin, C. Williamson, W. K. Collins, and D. Dahlin, "Sequential extraction versus comprehensive characterization of heavy metal species in brownfield soils," Environmental Forensics, vol. 3, no. 2, pp. 191-201, 2002.

[31] L. Sun, Y. Geng, J. Sarkis et al., "Measurement of polycyclic aromatic hydrocarbons (PAHs) in a Chinese brownfield redevelopment site: the case of Shenyang," Ecological Engineering, vol. 53, pp. 115-119, 2013.

[32] S. Martinat, J. Navratil, J. B. Hollander et al., "Re-reuse of regenerated brownfields: lessons from an Eastern European post-industrial city," Journal of Cleaner Production, vol. 188, pp. 536-545, 2018.

[33] S. Schädler, M. Morio, S. Bartke, R. Rohr-Zänker, and M. Finkel, "Designing sustainable and economically attractive brownfield revitalization options using an integrated assessment model," Journal of Environmental Management, vol. 92, no. 3, pp. 827-837, 2011.

[34] L. Pizzol, A. Zabeo, P. Klusáček et al., “Timbre brownfield prioritization tool to support effective brownfield regeneration," Journal of Environmental Management, vol. 166, pp. 178-192, 2016.

[35] E. Rizzo, M. Pesce, L. Pizzol et al., "Brownfield regeneration in Europe: identifying stakeholder perceptions, concerns, attitudes and information needs," Land Use Policy, vol. 48, pp. 437-453, 2015.

[36] F. Cheng, S. Geertman, M. Kuffer, and Q. Zhan, "An integrative methodology to improve brownfield redevelopment planning in Chinese cities: a case study of Futian, Shenzhen," Computers, Environment and Urban Systems, vol. 35, no. 5, pp. 388-398, 2011.

[37] E. L. Rall and D. Haase, "Creative intervention in a dynamic city: a sustainability assessment of an interim use strategy for brownfields in Leipzig, Germany," Landscape and Urban Planning, vol. 100, no. 3, pp. 189-201, 2011.

[38] S. Bartke and R. Schwarze, "No perfect tools: trade-offs of sustainability principles and user requirements in designing support tools for land-use decisions between greenfields and brownfields," Journal of Environmental Management, vol. 153, pp. 11-24, 2015.

[39] M. Chrysochoou, K. Brown, G. Dahal et al., "A GIS and indexing scheme to screen brownfields for area-wide redevelopment planning," Landscape and Urban Planning, vol. 105, no. 3, pp. 187-198, 2012.

[40] S. Alker, V. Joy, P. Roberts, and N. Smith, "The definition of brownfield," Journal of Environmental Planning and Management, vol. 43, no. 1, pp. 49-69, 2000.

[41] G. Thornton, M. Franz, D. Edwards, G. Pahlen, and P. Nathanail, "The challenge of sustainability: incentives for brownfield regeneration in Europe," Environmental Science \& Policy, vol. 10, no. 2, pp. 116-134, 2007.

[42] B. Frantál, B. Greer-Wootten, P. Klusáček, T. Krejčí, J. Kunc, and S. Martinát, "Exploring spatial patterns of urban brownfields regeneration: the case of Brno, Czech Republic," Cities, vol. 44, pp. 9-18, 2015.

[43] M. Morio, S. Schädler, and M. Finkel, "Applying a multicriteria genetic algorithm framework for brownfield reuse optimization: improving redevelopment options based on stakeholder preferences," Journal of Environmental Management, vol. 130, pp. 331-346, 2013.

[44] S. Schaedler, M. Finkel, A. Bleicher, M. Morio, and M. Gross, "Spatially explicit computation of sustainability indicator values for the automated assessment of land-use options," Landscape and Urban Planning, vol. 111, p. 113, 2013.

[45] J. Navratil, K. Picha, S. Martinat, P. C. Nathanail, K. Tureckova, and A. Holesinska, "Resident's preferences for urban brownfield revitalization: insights from two Czech cities," Land Use Policy, vol. 76, pp. 224-234, 2018.

[46] P. Klusáček, F. Alexandrescu, R. Osmana et al., "Good governance as a strategic choice in brownfield regeneration: regional dynamics from the Czech republic," Land Use Policy, vol. 73, pp. 29-39, 2018.

[47] C. De Sousa, "Contaminated sites: the Canadian situation in an international context," Journal of Environmental Management, vol. 62, no. 2, pp. 131-154, 2001.

[48] C. A. De Sousa, "Brownfield redevelopment in Toronto: an examination of past trends and future prospects," Land Use Policy, vol. 19, no. 4, pp. 297-309, 2002. 
[49] H. Bacot and C. O'Dell, "Establishing indicators to evaluate brownfield redevelopment," Economic Development Quarterly, vol. 20, no. 2, pp. 142-161, 2006.

[50] R. Clemente, W. Hartley, P. Riby, N. M. Dickinson, and N. W. Lepp, "Trace element mobility in a contaminated soil two years after field-amendment with a greenwaste compost mulch," Environmental Pollution, vol. 158, no. 5, pp. 1644-1651, 2010.

[51] Y.-T. Tang and C. P. Nathanail, "Sticks and stones: the impact of the definitions of brownfield in policies on socio-economic sustainability," Sustainability, vol. 4, no. 5, pp. 840-862, 2012.

[52] V. Maliene, L. Wignall, and N. Malys, "Brownfield regeneration: waterfront site developments in liverpool and cologne," Journal of Environmental Engineering and Landscape Management, vol. 20, no. 1, pp. 5-16, 2012.

[53] A. S. Baeing and C. Wong, "Brownfield residential development: what happens to the most deprived neighbourhoods in England?" Urban Studies, vol. 49, no. 14, pp. 2989-3008, 2012.

[54] Y. Mashayekh, C. Hendrickson, and H. S. Matthews, "Role of brownfield developments in reducing household vehicle travel," Journal of Urban Planning and Development, vol. 138, no. 3, pp. 206-214, 2012.

[55] A. B. Salisbury, J. R. Reinfelder, F. J. Gallagher, and J. C. Grabosky, "Long-term stability of trace element concentrations in a spontaneously vegetated urban brownfield with anthropogenic soils," Soil Science, vol. 182, no. 2, pp. 69-81, 2017.

[56] H. Feng, W. Zhang, Y. Qian et al., "Synchrotron X-ray microfluorescence measurement of metal distributions inPhragmites australisroot system in the Yangtze river intertidal zone," Journal of Synchrotron Radiation, vol. 23, no. 4, pp. 937-946, 2016.

[57] T. Dixon, N. Otsuka, and H. Abe, "Critical success factors in urban brownfield regeneration: an analysis of "hardcore" sites in Manchester and Osaka during the economic recession," Environment and Planning A: Economy and Space, vol. 43, no. 4, pp. 961-980, 2011.

[58] B. Glumac, Q. Han, W. Schaefer, and E. van der Krabben, "Negotiation issues in forming public-private partnerships for brownfield redevelopment: applying a game theoretical experiment," Land Use Policy, vol. 47, pp. 66-77, 2015.

[59] T. K. BenDor, S. S. Metcalf, and M. Paich, "The dynamics of brownfield redevelopment," Sustainability, vol. 3, no. 6, pp. 914-936, 2011.

[60] I.-C. Chen and H.-W. Ma, "Using risk maps to link land value damage and risk as basis of flexible risk management for brownfield redevelopment," Chemosphere, vol. 90, no. 7, pp. 2101-2108, 2013.

[61] T. Dixon, "The Property development industry and sustainable urban brownfield regeneration in England: an analysis of case studies in Thames gateway and greater manchester," Urban Studies, vol. 44, no. 12, pp. 2379-2400, 2007.

[62] T. Dixon and D. Adams, "Housing supply and brownfield regeneration in a post-Barker World: is there enough brownfield land in England and Scotland?" Urban Studies, vol. 45, no. 1, pp. 115-139, 2008.

[63] N. Ahmad, Y. M. Zhu, J. Shao, and H. L. Lin, "Stakeholders' perspective on strategies to promote contaminated site remediation and brownfield redevelopment in developing countries: empirical evidence from Pakistan," Environmental Science and Pollution Research, vol. 27, no. 1, pp. 14614-14633, 2020.
[64] Q. Zhong, L. Zhang, Y. Zhu et al., “A conceptual framework for ex ante valuation of ecosystem services of brownfield greening from a systematic perspective," Ecosystem Health and Sustainability, vol. 6, no. 1, p. 1743206, 2020.

[65] Y. Zhang, C. Wang, W. Tian, and G. Zhang, "Determinants of purchase intention for real estate developed on industrial brownfields: evidence from China," Journal of Housing and the Built Environment, vol. 35, pp. 1261-1282, 2020.

[66] Q. Han, Y. Zhu, G. Ke, and H. Lin, "A two-stage decision framework for resolving brownfield conflicts," International Journal of Environmental Research and Public Health, vol. 16, no. 6, p. 1039, 2019.

[67] D. Baragaño, C. Boente, E. Rodríguez-Valdés et al., “Arsenic release from pyrite ash waste over an active hydrogeological system and its effects on water quality," Environmental Science and Pollution Research, vol. 27, no. 10, pp. 10672-10684, 2020.

[68] C. Boente, C. Sierra, E. Rodríguez-Valdés, J. M. MenéndezAguado, and J. R. Gallego, "Soil washing optimization by means of attributive analysis: case study for the removal of potentially toxic elements from soil contaminated with pyrite ash," Journal of Cleaner Production, vol. 142, pp. 2693-2699, 2017.

[69] A. J. Bates, J. P. Sadler, R. B. Greswell, and R. Mackay, "Effects of recycled aggregate growth substrate on green roof vegetation development: a six year experiment," Landscape and Urban Planning, vol. 135, pp. 22-31, 2015.

[70] A. J. Bates, J. P. Sadler, R. B. Greswell, and R. Mackay, "Effects of varying organic matter content on the development of green roof vegetation: a six year experiment," Ecological Engineering, vol. 82, pp. 301-310, 2015.

[71] P. Lesage, T. Ekvall, L. Deschênes, and R. Samson, "Environmental assessment of brownfield rehabilitation using two different life cycle inventory models," The International Journal of Life Cycle Assessment, vol. 12, no. 7, pp. 497-513, 2007.

[72] T. K. BenDor and S. Metcalf, "Conceptual modeling and dynamic simulation of brownfield redevelopment," in Proceedings of the 23rd International Conference of the System Dynamics Society, Boston, MA, USA, July 2005.

[73] X. Liu, X. Li, X. Shi, X. Zhang, and Y. Chen, "Simulating landuse dynamics under planning policies by integrating artificial immune systems with cellular automata," International Journal of Geographical Information Science, vol. 24, no. 5, pp. 783-802, 2010. 